\title{
Folinic acid-responsive seizures
}

\author{
INSERM
}

\section{Source}

INSERM. (1999). Orphanet: an online rare disease and orphan drug data base. Folinic acidresponsive seizures. ORPHA:79097

Folinic acid-responsive seizures is a very rare neonatal epileptic encephalopathy disorder characterized clinically by myoclonic and clonic, or clonic seizures associated with apnea occurring several hours to 5 days after birth and responding to folinic acid. 